\title{
Urban growth in developing countries: A review of projections and predictions
}

Martin Brockerhoff

Population Council

Follow this and additional works at: https://knowledgecommons.popcouncil.org/departments_sbsr-pgy

Part of the Demography, Population, and Ecology Commons, Family, Life Course, and Society Commons, International Public Health Commons, and the Place and Environment Commons How does access to this work benefit you? Let us know!

\section{Recommended Citation}

Brockerhoff, Martin. 1999. "Urban growth in developing countries: A review of projections and predictions," Policy Research Division Working Paper no. 131. New York: Population Council. Version of record: https://doi.org/10.1111/j.1728-4457.1999.00757.x

This Working Paper is brought to you for free and open access by the Population Council. 


\title{
U rban growth in developing countries: A review of projections and predictions.
}

\author{
M artin B rockerhoff
}

1999 No. 131 


\title{
Urban Growth in Developing Countries: A Review of Projections and Predictions
}

\author{
Martin Brockerhoff
}

Martin Brockerhoff is Associate, Policy Research Division, Population Council. 


\begin{abstract}
Comparison of the United Nations' earliest and most recent projections to the year 2000 suggests that urban and city growth in developing regions has occurred much more slowly than was anticipated as recently as 1980. A modified "urban population explosion" in developing countries since the 1970s conforms to explanatory models of urban growth developed by economists around 1980. Trends in productivity and terms of trade, in particular, have been highly favorable to agriculture as compared to manufacturing, presumably slowing migration to urban centers. Increases in national population growth rates have produced less than commensurate increases in rates of city growth, further supporting an economic and migration-related explanation for unexpectedly slow recent urban growth. Despite the efforts of the United Nations to maintain reliable statistics on urban and city populations, urban population projections should be interpreted with caution because of inadequacies of the data on which they are based. Moreover, current projections that virtually all world population growth in the future will occur in urban areas of developing countries may be misconstrued, if the forces that have retarded urban growth in recent years persist.
\end{abstract}

This material may not be reproduced without written permission from the author. 
Because the year 2000 figures prominently in urban population projections, it is timely to assess whether the United Nations' earliest projections of urban population growth in developing countries, made in the 1970s, have been reasonably accurate, and if not, why. Despite being accompanied by advice to interpret urban population projections with caution and not as forecasts (United Nations 1980), these early projections of rapid growth fueled common perceptions of an impending "urban population explosion" in poor countries (Bairoch 1988; Schiffer 1989), while providing many governments with a pretext for concentrating economic resources and focusing population control efforts, such as restrictions on in-migration, in big cities (Badshah 1996; United Nations 1981).

The recent availability of data from the 1990-round censuses makes it equally opportune to examine whether influential predictive models of urban and city growth in developing countries, published around 1980, have remained robust over time. The most prominent of these models were pessimistic in assessing the prospects for modifying rapid urban growth through direct interventions in cities and against urban in-migration. Economists concluded that pricing policies biased in favor of cities, as well as national development strategies and global economic conditions that spurred manufacturing rather than agricultural productivity, made rapid urban growth until the year 2000 likely (Kelley and Williamson 1984b: Table 6.6). Meanwhile, demographers linked city growth rates closely with national population growth rates, implying that municipal authorities and planners were virtually powerless in controlling the future sizes of their cities (United Nations 1980: 43). These empirical studies supported Lipton's (1976) thesis of "urban bias," which contends that economic development policies of governments in low-income countries favor cities to such an extent as to undermine efforts to slow urban growth, including measures to discourage rural-to-urban migration.

Contradicting these scenarios of rapid growth, the United Nations and urban scholars have tentatively concluded that rates of urban and city growth in the developing world have been slower in recent decades than was once anticipated (Becker and Morrison 1999; Satterthwaite 1996; United Nations 1998). A glaring and often-cited example is Mexico City, whose estimated current population of about 18 million does not approximate the more than 30 million inhabitants projected for 2000 as recently as 1980 (United Nations 1980). ${ }^{1}$ Such discrepancy reflects in part the limitations of the data to which UN urban estimation and projection procedures are applied. Yet, descriptive accounts 
are lacking to indicate whether the experience of Mexico City is unique or whether it is illustrative of widespread, highly erroneous urban population projections at the regional, national, and city levels in developing countries. Moreover, it is not known whether slower-than-expected urban growth has been consistent with economic trends that influence migration between urban and rural areas, or with demographic factors, such as declining national population growth. An examination of the patterns and causes of unexpectedly slow urban growth in recent years is needed to improve the basis for urban population projections in the future, and thereby assist development planning. Such an exercise is also important for assessing the plausibility of current projections according to which virtually all world population growth in the near future will occur in urban areas of the developing world (United Nations 1998).

This article has two objectives: (1) to scrutinize the slower than formerly anticipated urban growth noted by the United Nations for the developing world as a whole in recent years at lower levels of population aggregation — regions, countries, and citiesso as to ascertain whether this phenomenon is common throughout the South or, rather, is particular to certain areas and sensitive to population size; and (2) to reevaluate the strength of predictive models of city and urban growth developed around 1980 by demographers and economists, as typified respectively by Preston (1979) and Kelley and Williamson (1984a), in light of urban population data now available from the 1980- and 1990-round censuses, as well as data accumulated since 1980 that may reflect changes in potent explanatory factors (for instance, economic conditions). Reexamination of these models may indicate the forces responsible for a slowdown of urban growth in recent years, if this phenomenon has indeed occurred.

\section{AN ASSESSMENT OF URBAN POPULATION PROJECTIONS TO}

\section{THE YEAR 2000}

The accuracy of population projections to 2000 and later dates can be assessed most conclusively through ex post facto comparisons of observed populations in the twenty-first century to currently available published statistics. For evaluation at present, one must accept the most recent UN urban projections to 2000, revised in 1996, as reasonably correct given their recent data base and short projection period. Because the 
methodology employed by the United Nations to estimate and project national urban and rural populations was reformulated in the late 1970s (United Nations 1980: 9-11) and has not changed since then (United Nations 1998: 31-36), the most recent figures serve as a benchmark for determining to what extent subsequent developments and the use of newly available data affected the accuracy of projections made in $1980 .{ }^{2}$ Comparison of these sets of projections is also appropriate to detect an unanticipated slowdown of urban growth, because the latest projections make full use of all available data from the 1980- and 1990-round censuses, whereas the earlier set of projections did not.

Table 1 presents the size of the urban population in developing regions and subregions in the year 2000, as projected in 1980 and 1996 by the United Nations. The figures in the table are derived from an identical group of 134 countries classified as less developed in 1980 (therefore excluding those countries in the former Soviet Union that are now classified as less developed) whose definitions of urban did not change between the two years. ${ }^{3}$

The most recent United Nations projections foresee a less developed country (LDC) urban population of somewhat under 1.9 billion in the year 2000, more than 10 percent (or 222 million) lower than the somewhat over 2.1 billion expected in 1980 (13 percent lower if China is excluded). In contrast, the size of the projected total population has been revised downward by only 2 percent, and the size of the rural population has been revised upward by 4 percent. These percentage changes suggest that the United Nations has been much more successful in projecting accurately the total LDC population than the urban population. However, roughly half (110 million) of the downward revision of the projected urban population is attributable to the projected total population growth in the developing world that was slower than anticipated in $1980 .{ }^{4}$ Slower total population growth, in turn, has largely resulted from faster-than-expected fertility declines in LDCs. ${ }^{5}$

The 1996 projections of the size of the 2000 urban populations are lower than those projected in 1980 in all major developing regions and in 10 of the 12 subregions listed in Table 1. Most striking is the shift in these figures for Latin America and the Caribbean: some 17 percent fewer urbanites according to the 1996 projection (which corresponds to a sharply revised average annual urban growth rate between 1980 and 
Table 1 Projected urban, rural, and total populations of developing regions to the year 2000 (in millions)

\begin{tabular}{lrrr}
\hline & \multicolumn{2}{c}{ As projected in } & \\
\cline { 2 - 3 } & $\mathbf{1 9 8 0}$ & $\mathbf{1 9 9 6}$ & Percent change \\
\hline Urban areas of LDCs & & & \\
All developing regions & & & \\
$\quad$ Excluding China & $2,115.5$ & $1,893.4$ & -10.5 \\
Africa & $1,672.3$ & $1,455.1$ & -13.0 \\
$\quad$ Eastern & 345.8 & 309.7 & -10.4 \\
$\quad$ Middle & 70.5 & 64.2 & -8.9 \\
$\quad$ Northern & 45.2 & 33.5 & -25.9 \\
$\quad$ Southern & 111.9 & 89.1 & -20.3 \\
$\quad$ Western & 32.6 & 26.2 & -19.6 \\
Asia & 85.5 & 96.6 & 12.9 \\
$\quad$ Eastern & $1,299.0$ & $1,194.2$ & -8.1 \\
South-central & 508.3 & 502.0 & -1.3 \\
Southeastern & 517.6 & 431.5 & -15.1 \\
$\quad$ Western & 207.7 & 192.7 & -7.2 \\
Latin America and $_{\text {the Caribbean }}$ & 65.4 & 68.0 & 4.0 \\
$\quad$ Caribbean & & & \\
Central America & 466.2 & 387.6 & -16.9 \\
$\quad$ South America & 28.8 & 23.9 & -17.0 \\
Oceania & 124.6 & 91.2 & -26.8 \\
Rural areas of LDCs & 312.9 & 272.5 & -12.9 \\
Total & 4.6 & 2.0 & -57.1 \\
\hline
\end{tabular}

a Projections in both years are based on the 134 countries that (1) were classified as less developed in 1980 and for which data were available in 1980 and 1996, and (2) whose definitions of urban did not change between the two years. $\quad{ }^{\mathrm{b}}$ Excluding Japan. $\quad{ }^{\mathrm{c}}$ Excluding Australia and New Zealand. SOURCES: United Nations 1980, 1998.

2000, from 3.31 percent to 2.54 percent). The urban population of Asia in 2000 as projected in 1996 is 105 million less than was projected in 1980, while recent urban growth in Africa—frequently claimed as occurring at high levels unprecedented in history—has 
been apparently occurring at an appreciably slower pace than was anticipated in 1980 (at roughly 4.3 percent per year, on average, rather than 4.8 percent).

Table 2 shows that the consistent pattern among regions_-of much slower urban growth than was expected earlier-masks a high degree of diversity in the accuracy of projections among countries within subregions, even between adjacent countries (for instance, Mozambique and Malawi). ${ }^{6}$ The countries in Table 2 show the extremes of differences within subregions. In Middle Africa, for example, the Congo's urban population was projected in 1996 to number almost 2 million in 2000, about 40 percent higher than was projected in 1980. In contrast, in the neighboring Democratic Republic of the Congo (formerly Zaire), the 1996 projected urban population is 12 million, or almost one-half fewer than was projected in 1980. Since rates of natural increase are very similar in neighboring countries throughout Africa, such large discrepancies-great upward revisions in one country and massive downward revisions in another-suggest that early projections of urban growth in African countries were based on too few reliable data sources to be taken seriously, or that these projections were subsequently nullified by unforeseen patterns of migration.

In Southeastern Asia, Singapore and Vietnam exhibit a pattern similar to that of the two countries of Middle Africa just cited, with Vietnam expected to have in 2000 just over half the urban population that was projected in 1980. In Latin America, the 1980 projections of the urban population for 2000 have been revised downward in 1996 for all countries except Argentina, Bolivia, and Paraguay. In El Salvador the 1996 projection was lower by 36 percent. Upward revisions of anticipated urban populations in countries such as Lesotho and Oman are not surprising, given the small initial size of the urban populations. Revisions of the magnitude made, for example, for Vietnam and South Africa, however, are significant also in terms of the absolute numbers of persons involved.

Comparison of Tables 1 and 2 reveals that the much-revised urban projections of subregions correspond closely to revised projections for the largest countries in those subregions. This is clearly the case with Egypt, China, India, Brazil, Mexico, and their respective subregions. The exceptional upward revision in 1996 as compared to 1980 of Western Africa's urban population projected to 2000, by 13 percent, is largely a result of 
Table 2 Extremes of intraregional differences in UN urban population projections to the year 2000 (in thousands)

\begin{tabular}{|c|c|c|c|c|}
\hline \multirow[b]{2}{*}{ Region } & \multirow[b]{2}{*}{ Country $^{\mathrm{a}}$} & \multicolumn{2}{|c|}{ As projected in } & \multirow[b]{2}{*}{ Percent change $^{b}$} \\
\hline & & 1980 & 1996 & \\
\hline \multicolumn{5}{|l|}{ Africa } \\
\hline Eastern & $\begin{array}{l}\text { Mozambique } \\
\text { Malawi }\end{array}$ & $\begin{array}{l}3,199 \\
6,489\end{array}$ & $\begin{array}{l}7,869 \\
1,686\end{array}$ & $\begin{array}{l}146.0 \\
-74.0\end{array}$ \\
\hline Middle & $\begin{array}{l}\text { Rep. of Congo } \\
\text { Dem. Rep. of Congo } \\
\text { (Zaire) }\end{array}$ & $\begin{array}{r}1,347 \\
27,839\end{array}$ & $\begin{array}{r}1,865 \\
15,670\end{array}$ & $\begin{array}{r}38.5 \\
-45.4\end{array}$ \\
\hline Northern & $\begin{array}{l}\text { Libya } \\
\text { Sudan }\end{array}$ & $\begin{array}{r}3,405 \\
16,551\end{array}$ & $\begin{array}{r}5,597 \\
10,772\end{array}$ & $\begin{array}{r}64.4 \\
-34.9\end{array}$ \\
\hline Southern & $\begin{array}{l}\text { Lesotho } \\
\text { South Africa }\end{array}$ & $\begin{array}{r}217 \\
30,109\end{array}$ & $\begin{array}{r}641 \\
23,291\end{array}$ & $\begin{array}{l}195.4 \\
-22.4\end{array}$ \\
\hline Western & $\begin{array}{l}\text { Senegal } \\
\text { Ghana }\end{array}$ & $\begin{array}{r}3,002 \\
10,843\end{array}$ & $\begin{array}{l}4,463 \\
7,644\end{array}$ & $\begin{array}{r}48.7 \\
-29.5\end{array}$ \\
\hline Largest countries & $\begin{array}{l}\text { Nigeria (Western) } \\
\text { Egypt (Northern) }\end{array}$ & $\begin{array}{l}45,041 \\
37,048\end{array}$ & $\begin{array}{l}55,561 \\
31,297\end{array}$ & $\begin{array}{r}25.8 \\
-16.5\end{array}$ \\
\hline \multicolumn{5}{|l|}{ Asia } \\
\hline Eastern & $\begin{array}{l}\text { Hong Kong } \\
\text { Dem. Rep. of Korea }\end{array}$ & $\begin{array}{r}5,210 \\
20,006\end{array}$ & $\begin{array}{r}6,097 \\
15,021\end{array}$ & $\begin{array}{r}17.0 \\
-24.9\end{array}$ \\
\hline South-central & $\begin{array}{l}\text { Nepal } \\
\text { Sri Lanka }\end{array}$ & $\begin{array}{l}2,275 \\
8,860\end{array}$ & $\begin{array}{l}2,893 \\
4,434\end{array}$ & $\begin{array}{r}27.2 \\
-48.8\end{array}$ \\
\hline Southeastern & $\begin{array}{l}\text { Singapore } \\
\text { Vietnam }\end{array}$ & $\begin{array}{r}2,453 \\
27,574\end{array}$ & $\begin{array}{r}3,587 \\
15,891\end{array}$ & $\begin{array}{r}46.2 \\
-42.4\end{array}$ \\
\hline Western & $\begin{array}{l}\text { Oman } \\
\text { Lebanon }\end{array}$ & $\begin{array}{r}248 \\
5,269\end{array}$ & $\begin{array}{l}2,282 \\
2,951\end{array}$ & $\begin{array}{l}820.2 \\
-44.3\end{array}$ \\
\hline Largest countries & $\begin{array}{l}\text { China (Eastern) } \\
\text { India (South-central) }\end{array}$ & $\begin{array}{l}443,213 \\
360,688\end{array}$ & $\begin{array}{l}438,263 \\
286,323\end{array}$ & $\begin{array}{r}-1.1 \\
-20.6\end{array}$ \\
\hline \multicolumn{5}{|c|}{ Latin America and the Caribbean } \\
\hline Caribbean & $\begin{array}{l}\text { Haiti } \\
\text { Dominican Republic }\end{array}$ & $\begin{array}{l}2,765 \\
7,834\end{array}$ & $\begin{array}{l}2,727 \\
5,537\end{array}$ & $\begin{array}{r}-1.4 \\
-29.3\end{array}$ \\
\hline Central America & $\begin{array}{l}\text { Costa Rica } \\
\text { El Salvador }\end{array}$ & $\begin{array}{l}2,067 \\
4,628\end{array}$ & $\begin{array}{l}1,970 \\
2,947\end{array}$ & $\begin{array}{r}-4.7 \\
-36.3\end{array}$ \\
\hline South America & $\begin{array}{l}\text { Argentina } \\
\text { Colombia }\end{array}$ & $\begin{array}{l}28,875 \\
41,779\end{array}$ & $\begin{array}{l}33,089 \\
29,154\end{array}$ & $\begin{array}{r}14.6 \\
-30.2\end{array}$ \\
\hline Largest countries & $\begin{array}{l}\text { Brazil (South) } \\
\text { Mexico (Central) }\end{array}$ & $\begin{array}{l}163,027 \\
102,293\end{array}$ & $\begin{array}{r}137,527 \\
73,553\end{array}$ & $\begin{array}{l}-15.6 \\
-28.1\end{array}$ \\
\hline
\end{tabular}

${ }^{a}$ Excluding countries with an estimated total population less than 2 million in 1995 (United Nations 1998). $\quad{ }^{\mathrm{b}}$ Median change for 134 developing countries: -7.5 percent.

SOURCES: United Nations 1980, 1998. 
a 26 percent upward revision for urban Nigeria, where about 60 percent of Western Africa's urbanites reside. The seemingly accelerated urban growth of Nigeria in the 1980s and 1990s is remarkable given that the projected total population of the country in 2000 — which was much influenced by the surprising results of the 1991 census-was revised downward by 18 percent between 1980 and 1996, from 135 to 111 million; as a result of the two revisions, Nigeria's expected level of urbanization in 2000 has been changed from 33 to 44 percent. $^{7}$ The consistency of the two projections for China, despite change in the national definition of urban during 1980-96, has been explained by Banister (1997: 79-80). ${ }^{8}$ The revised projection for urban India—of 75 million fewer urban residents projected in 1996 than was projected in 1980-is by far the largest absolute change of any country, and represents a decrease in the 1980-2000 average annual urban growth rate from 4.24 percent to 2.95 percent. $^{9}$

Table 3 compares projections to the year 2000 made in 1980 and 1996 for the largest cities of the 15 most populous countries in each of the three major developing regions. The same definition of each city - as an agglomeration, the city proper, or by the application of some other criterion-is used for both years. Most of the early projections of LDC city growth appear to have been far too high, indicating the weakness of data on which city population statistics, in particular, are calculated. In each region, the 2000 population projected in 1980 has been lowered in the 1996 projections in 9 or 10 of the 15 cities. The 13-million downward revision of the projection for Mexico City is hardly exceptional: projections for Shanghai, Jakarta, Baghdad, and São Paulo have each been lowered by more than 6 million. The relative over-projection of Mexico City's 2000 population in 1980 as compared to 1996 by 42 percent is exceeded by the shift for several smaller cities in Africa as well as by Kuala Lumpur. A remarkable change, as compared to the general pattern of cities, is the threefold increase in the projected 2000 population of Lagos, which accounts for 85 percent of the upward revision of Nigeria's urban population. In 1980 it was projected that 389 cities would reach sizes of at least 750,000 by 1995; according to the most recent estimates 239 did, 150 did not (United Nations 1980, 1998). Projections in 1980 to the year 2000 were far less accurate for cities than for the urban population at large. For example, whereas the urban population of developing regions has been revised downward by 10.5 percent (and by a median 
Table 3 Projected population in 2000 of the largest city in the 15 largest countries in each developing region (in thousands)

\begin{tabular}{|c|c|c|c|c|}
\hline \multirow[b]{2}{*}{ Region/country } & \multirow[b]{2}{*}{ Largest city } & \multicolumn{2}{|c|}{ As projected in } & \multirow[b]{2}{*}{ Percent change $^{a}$} \\
\hline & & 1980 & 1996 & \\
\hline \multicolumn{5}{|l|}{ Africa } \\
\hline Nigeria & Lagos & 4,518 & 13,488 & 198.5 \\
\hline Egypt & Cairo & 13,058 & 10,772 & -17.5 \\
\hline Ethiopia & Addis Ababa & 5,600 & 3,112 & -44.4 \\
\hline Dem. Rep. of Congo & Kinshasa & 8,411 & 5,068 & -39.7 \\
\hline South Africa & Cape Town & 2,850 & 3,092 & 8.5 \\
\hline Tanzania & Dar es Salaam & 4,645 & 2,051 & -55.8 \\
\hline Algeria & Algiers & 2,643 & 4,447 & 68.3 \\
\hline Kenya & Nairobi & 4,869 & 2,320 & -52.4 \\
\hline Sudan & Khartoum & 5,079 & 2,748 & -45.9 \\
\hline Morocco & Casablanca & 4,624 & 3,535 & -23.5 \\
\hline Uganda & Kampala & 3,015 & 1,207 & -60.0 \\
\hline Ghana & Accra & 3,842 & 2,010 & -47.7 \\
\hline Mozambique & Maputo & 2,619 & 3,017 & 15.2 \\
\hline Madagascar & Antananarivo & 1,880 & 1,128 & -40.0 \\
\hline Ivory Coast & Abidjan & 1,800 & 3,359 & 86.6 \\
\hline \multicolumn{5}{|l|}{ Asia } \\
\hline China & Shanghai & 22,677 & 14,173 & -37.5 \\
\hline India & Bombay & 17,056 & 18,042 & 5.8 \\
\hline Indonesia & Jakarta & 16,591 & 9,815 & -40.8 \\
\hline Pakistan & Karachi & 11,774 & 11,774 & 0 \\
\hline Bangladesh & Dhaka & 9,725 & 10,979 & 12.9 \\
\hline Vietnam & Ho Chi Minh City & 4,502 & 3,678 & -18.3 \\
\hline Iran & Teheran & 11,329 & 7,380 & -34.9 \\
\hline Philippines & Metro Manila & 12,313 & 10,818 & -12.1 \\
\hline Thailand & Bangkok & 11,936 & 7,221 & -39.5 \\
\hline Myanmar & Yangon & 4,747 & 4,458 & -6.1 \\
\hline Rep. of Korea & Seoul & 14,246 & 12,215 & -14.3 \\
\hline Afghanistan & Kabul & 1,270 & 2,716 & 113.9 \\
\hline Dem. Rep. of Korea & Pyongyang & 2,240 & 2,726 & 21.7 \\
\hline Iraq & Baghdad & 11,125 & 4,796 & -56.9 \\
\hline Malaysia & Kuala Lumpur & 2,552 & 1,378 & -46.0 \\
\hline
\end{tabular}


Table 3 (continued)

\begin{tabular}{|c|c|c|c|c|}
\hline \multirow[b]{2}{*}{ Region/country } & \multirow[b]{2}{*}{ Largest city } & \multicolumn{2}{|c|}{ As projected in } & \multirow[b]{2}{*}{ Percent change $^{a}$} \\
\hline & & 1980 & 1996 & \\
\hline \multicolumn{5}{|l|}{$\begin{array}{l}\text { Latin America and } \\
\text { the Caribbean }\end{array}$} \\
\hline Brazil & São Paulo & 25,796 & 17,711 & -31.3 \\
\hline Mexico & Mexico City & 31,025 & 18,131 & -41.6 \\
\hline Colombia & Bogotá & 6,834 & 6,834 & 0 \\
\hline Argentina & Buenos Aires & 12,104 & 12,431 & 2.7 \\
\hline Peru & Lima & 8,930 & 7,443 & -16.7 \\
\hline Venezuela & Caracas & 5,209 & 3,153 & -39.5 \\
\hline Chile & Santiago & 5,760 & 5,261 & -8.7 \\
\hline Ecuador & Guayaquil & 2,370 & 2,127 & -10.3 \\
\hline Guatemala & Guatemala City & 2,084 & 2,697 & 29.4 \\
\hline Cuba & Havana & 3,213 & 2,302 & -28.4 \\
\hline Dominican Republic & Santo Domingo & 4,176 & 3,601 & -13.8 \\
\hline Bolivia & La Paz & 1,963 & 1,458 & -25.7 \\
\hline Haiti & Port-au-Prince & 1,558 & 1,791 & 15.0 \\
\hline Honduras & Tegucigalpa & 1,150 & 1,241 & 7.9 \\
\hline El Salvador & San Salvador & 895 & 1,415 & 58.1 \\
\hline
\end{tabular}

${ }^{a}$ Median change for LDC cities with at least 750,000 residents in $1995=-15.1$ percent.

NOTE: Within each region the order of listing is according to population size of country in 1996. SOURCE: United Nations 1980, 1998.

average of -7.5 percent among all developing countries), the projected population of the 239 cities with at least 750,000 residents in these countries in 1995 has been lowered, on average, by 15.1 percent. $^{10}$

Figure 1 summarizes salient aspects of the apparent slowdown of urban growth in the developing world during 1980-2000 (excluding China). Undoubtedly, most total population growth has been urban (a combined result of urban natural increase and net rural-to-urban migration), and the component of urban growth within total growth will certainly increase in the future (United Nations 1998). Nonetheless, the average annual rate of urban growth during the last two decades of the twentieth century, which was projected in 1980 to exceed 4 percent, is anticipated to be 3.4 percent according to the 
Figure 1 Measures of urban population growth between 1980 and 2000 in developing countries, as projected in 1980 and 1996 (excluding China)
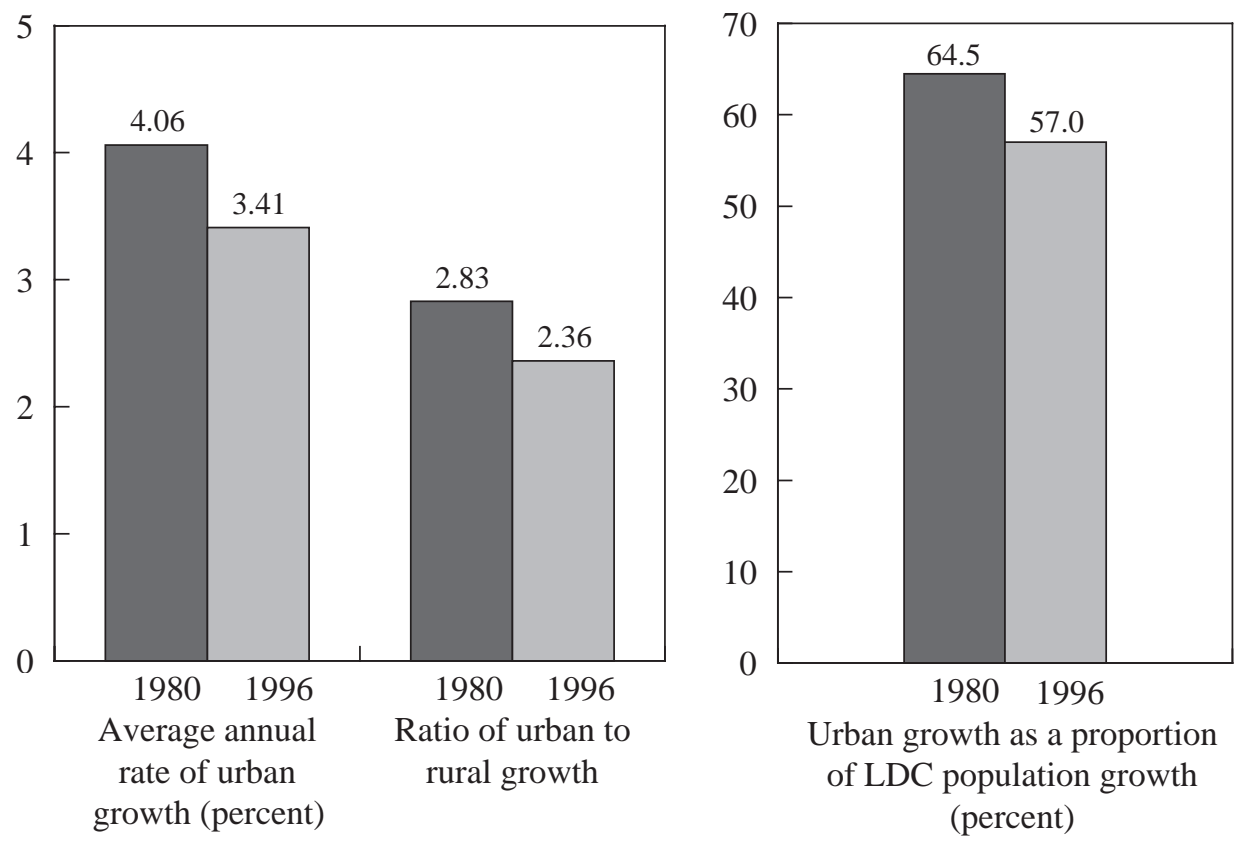

1996 projections. The changed outlook implies a 1980-2000 urban population increase of 98 percent rather than 127 percent. The pace of urbanization in 1996 appears more modest than was the case in 1980: between 1980 and 2000 the urban population is projected to be growing 2.4 times, rather than 2.8 times, more quickly than the rural population. And whereas in the 1980 projections 65 percent of the 1980-2000 population growth in developing countries was expected to occur in urban areas, this figure in the 1996 projections has been revised downward to 57 percent. This last comparison raises doubt about the reliability of current UN projections according to which over 90 percent of LDC population growth during 2000-25 will occur in urban areas (United Nations 1998), if one assumes that the factors that contributed to slower urban growth in the 1980s and 1990s will persist in the future and have not been fully accounted for in the most recent set of projections. 


\section{SOURCES OF CITY GROWTH SINCE THE 1970S}

While the UN's earliest projections of year 2000 urban and city populations in the developing world, made in the late 1970s, were generally far too high as compared to projections made in 1996 (which presumably are more accurate given the recency of the information on current population size and the much shorter projection period), there has also been considerable variation among countries and cities in the size and direction of change from the earlier to the later projections. The substantial revision of projections may be to some extent an artifact of assumptions that underlie the UN's methodology. This hypothesis could be explored by applying alternative assumptions to the data used by the UN in 1980 to make urban population projections to 2000 and then assessing whether results more closely approximate the populations projected in 1996 than did the projections published in 1980. At present, such an analysis can only be undertaken by the United Nations Population Division; the specific data used for projections in 1980 are not presented in any publication and cannot be identified with certainty from UN Demographic Yearbooks. An alternative approach is to examine potential sources of the recent slowdown and variation in urban and city growth based on existing theory of the underlying determinants of such growth, taking advantage of abundant population and development data collected for developing countries in recent years.

Preston (1979) and the UN Population Division (1980) analyzed the effects of several variables on intercensal growth rates of 1,211 cities in more and less developed countries (excluding China) between the 1960- and 1970-round censuses; no analysis of this scale has been conducted for developing countries alone or since that time. The most striking finding was an almost perfect association between national population growth rates and city growth rates: a 1 percent increase in the former resulted in a 1.002 percent increase in the latter. For example, if a country with an annual population growth rate of 3 percent experienced average city growth rates of 4 percent, then a country that experienced 4 percent growth had cities growing, on average, by 5.002 percent per annum. From this finding, one could conclude that the same forces fuel population growth in cities as in the countries in which they are located and thus, by implication, that high natural increase in rural areas does not propel cityward migration, nor are programs that modify natural increase (for instance, family planning and child survival programs) dif- 
ferentially effective in cities and in the countryside. Other notable results of the investigation just cited were that levels of economic development and performance positively affect city growth rates, whereas rates are significantly lower in more urbanized countries, and higher in Latin American countries, than elsewhere.

Table 4 replicates the analysis of Preston and the United Nations for 1,154 cities of developing countries only, based on city population data compiled from UN Demographic Yearbooks covering a span of 26 years (1971-97). This sample represents all cities in the developing world whose population sizes are reported for two time pointsbefore and after 1980, and at least eight years apart—and whose population size was at least 100,000 at the earlier date. ${ }^{11}$ On average the period covered is 1977-90, although for some cities estimates extend to 1996. Independent variables are derived from United Nations and World Bank publications for the same years as estimates of city size. While alternative measures of the variables may be preferable (for instance, adjusting conventional gross national product and gross domestic product according to purchasing power), this would preclude strict comparison to results of the Preston/UN study. The findings of this earlier study are shown in the final column of the table.

Analyses of the earlier and more recent periods show little consistency of results. One constant determinant in size and direction of effect is the annual growth rate of national GDP per capita: a 1 percent increase raises city growth rates by roughly 0.2 percent (or 2 per thousand persons). This is not surprising, as fast-growing LDC economies (for instance, in East Asia) presumably stimulate demand for labor in urban industry, manufacturing, and services, a situation conducive to net urban in-migration. Because cities are the historical engines of national economic growth, reverse causality could also be hypothesized from this relationship (that is, city population growth may be driving national economic growth). As Preston observes, however, it is unlikely that the average city is large enough for its population growth to contribute substantially to measured national economic growth during a short period of years.

On balance, results indicate that factors that drove city growth in the 1960s and 1970s have had markedly different effects on LDC city growth rates in recent years. Initial levels of GNP per capita are generally irrelevant to rates of city growth in subsequent years ( $\beta=0.042, p=.728$ ). The importance of national economic conditions there- 
Table 4 Effects of demographic, economic, and political variables on city growth rates, 1960s-1990s (annual percentage growth rates)

\begin{tabular}{|c|c|c|c|}
\hline \multirow[b]{2}{*}{ Variable } & \multirow[b]{2}{*}{$\begin{array}{l}\text { Unit of } \\
\text { measurement }\end{array}$} & \multicolumn{2}{|c|}{$\begin{array}{l}\text { Effect of one unit increase in } \\
\text { variable on city growth rate }\end{array}$} \\
\hline & & $\begin{array}{c}\text { LDCs only } \\
(1970 s-1990 s)\end{array}$ & $\begin{array}{c}\text { MDCs and LDCs } \\
\text { combined } \\
(1960 s-1970 s ; \\
\text { Preston 1979) } \\
\end{array}$ \\
\hline \multicolumn{4}{|l|}{ Demographic } \\
\hline $\begin{array}{l}\text { National population } \\
\text { growth rate }\end{array}$ & $\begin{array}{l}\text { Annual percentage } \\
\text { growth }\end{array}$ & $0.788 *$ & $1.002 *$ \\
\hline Natural log, initial city size & Persons & $-0.314 *$ & $-0.211 *$ \\
\hline Initial proportion urban & Urban percentage & $-0.062 *$ & $-0.029 *$ \\
\hline \multicolumn{4}{|l|}{ Economic } \\
\hline $\begin{array}{l}\text { Initial level of national } \\
\text { GNP per capita }\end{array}$ & $\begin{array}{l}\text { Thousands of US dollars } \\
\text { (LDCs only: initial year } \\
\text { of observation; Preston: } \\
\text { 1964) }\end{array}$ & 0.042 & $0.332 *$ \\
\hline $\begin{array}{l}\text { Growth rate of national } \\
\text { GDP per capita }\end{array}$ & $\begin{array}{l}\text { Annual percentage } \\
\text { growth (unadjusted to } \\
\text { purchasing power) }\end{array}$ & $0.189 *$ & $0.239 *$ \\
\hline \multicolumn{4}{|l|}{ Political } \\
\hline Capital city & 1 if capital city; 0 otherwise & $0.933 *$ & 0.589 \\
\hline Largest city & $\begin{array}{l}1 \text { if largest city in country; } \\
0 \text { otherwise }\end{array}$ & $1.152 *$ & 0.292 \\
\hline \multicolumn{4}{|l|}{ Regional } \\
\hline Latin America & $\begin{array}{l}1 \text { if in Latin America; } \\
0 \text { if Asia (excluding China } \\
\text { and India) }\end{array}$ & -0.294 & $0.614^{*}$ \\
\hline Africa & $\begin{array}{l}1 \text { if in Africa; } 0 \text { if Asia } \\
\text { (excluding China and India) }\end{array}$ & 0.372 & -0.025 \\
\hline China & $\begin{array}{l}1 \text { if in China; } 0 \text { if other Asia } \\
\text { (excluding India) }\end{array}$ & $0.817 *$ & - \\
\hline India & $\begin{array}{l}1 \text { if in India; } 0 \text { if other Asia } \\
\text { (excluding China) }\end{array}$ & $-0.544^{*}$ & - \\
\hline Constant & & 3.548 & 4.119 \\
\hline $\mathrm{R}^{2}$ & & 0.352 & 0.312 \\
\hline$(\mathrm{N})$ & & 1,154 & 1,212 \\
\hline \multicolumn{2}{|c|}{ Initial year of observation (mean) } & 1977 & 1962 \\
\hline \multicolumn{2}{|c|}{ Average duration of observation (years) } & 12.7 & 10.0 \\
\hline
\end{tabular}

NOTE: Based on cities with at least 100,000 residents in the initial year of observation. * $\mathrm{p}<.05 \quad$ a Partial regression coefficients.

SOURCES: Preston 1979; United Nations 1998; United Nations Demographic Yearbook (selected volumes 1971-97); World Bank World Tables (1985, 1995); World Bank World Development Indicators 1998; World Bank World Development Report (selected volumes 1977-97). 
fore appears ambiguous - economic progress as measured by GDP growth per capita spurs city growth, but it does so independent of a country's level of economic development. City growth rates are dampened in highly urbanized countries-in part owing to smaller proportions of potential in-migrants from rural areas-but the negative effects of urbanization levels on city growth are twice the magnitude reported for the 1960s, at about -.06 for every one percentage point increase in the initial proportion urban. Given our global sample of developing countries, inclusion of both primate and smaller cities, and statistical control of regional effects, this result suggests that counter-urbanization may be widespread across city sizes, and within the developing world, not restricted to cities of Latin America. ${ }^{12}$

Largest cities and capital cities of LDCs grew approximately 1.15 and 0.93 percent more quickly per annum than other cities, figures much higher (and more reliable statistically) than those reported by Preston. Therefore, presuming an average annual growth rate of 4.10 percent for other cities with at least 100,000 residents in the initial year of observation, cities that were both the national capital and the largest city in their countries grew, on average, by 6.18 percent per annum. Several factors account for these discrepancies with earlier findings. First, most of the cities analyzed for the 1960s are located in more developed countries, whereas our sample is exclusively from less developed countries where "urban bias," or the concentration of migration-inducing resources, has been much more pronounced in favor of major urban centers. Second, the largest and capital cities of most countries in sub-Saharan Africa, and of many countries in other regions, have populations of less than one million (United Nations 1998: Tables $11,12)$, population bases that are sufficiently small to translate population increments in absolute terms into high city growth rates. Third, high estimates for major urban centers run counter to the observed slowdown of mega-city growth rates since the 1970s, but these slow-growing giant cities_cities of 8 million or more residents-represent less than one percent of cities in the developing world with more than 100,000 inhabitants (hence included in our sample). Finally, support for these findings comes from other studies that indicate that cities of 1,000,000-5,000,000 residents grew more quickly than cities of 500,000-1,000,000 residents in developing regions during 1975-90 (Brockerhoff and Brennan 1998: 81). 
With respect to regional location, cities grew more rapidly in Latin America than elsewhere in the 1960s_ other factors being equal—but in recent years cities in Asia (excluding China and India from this reference category) grew more rapidly. The evidence of a sharp reduction in city growth in Latin America (relative to city growth in Asia), after controlling for national economic conditions that largely determine migration flows between cities and the countryside, points to Latin America's remarkable fertility decline - from an average total fertility rate of 6 in the early 1960s to 3 in the early 1990s (United Nations 1999) — as a likely major component of reduced city growth in the region. As compared to other Asian cities, the much more rapid growth of China's cities (greater by 0.8 percent per annum) and more sluggish growth of Indian cities (less by 0.54 percent per annum) is noteworthy insofar as China and India had virtually equivalent levels of urbanization and GNP per capita around $1980 .{ }^{13}$ As one might expect, these regional estimates for cities are consistent with the direction of revised UN projections for regional urban populations shown in Tables 1 and 2.

A striking result in Table 4, as compared to findings for the 1960s-1970s, is that a one percent increase in national population growth rates of LDCs increases city population growth rates by less than 0.8 percent, despite the fact that urban growth has been more rapid than total population growth since 1975. Indeed, 351 of the 1,154 cities in our sample experienced slower growth than their country's population during the period of observation. This finding suggests that small urban centers not included in this analysis, those with fewer than 100,000 residents, may be the fastest-growing settlements in the developing world, as has been noted elsewhere (UNCHS 1996). This result also supports the notion that, on the whole, there has not been net in-migration to LDC cities from smaller urban areas and rural areas; the net flow may be in the other direction, if weak city economies have discouraged out-migration from small areas and encouraged return migration to towns and villages. Such reverse flows from cities have been documented since the late 1980s, for instance in Ivory Coast and Guinea (Bocquier and Traoré 1998). Alternatively, technological progress and improved economic performance in agriculture, as compared to urban economic sectors, may have induced many potential migrants to remain in rural areas, a pattern consistent with some theories of rural demographic change (for instance, Boserup 1965) but at odds with others (for instance, Davis 
1963). Yet another explanation is that cities may have experienced a widening difference in rates of natural increase as compared to rates in smaller areas (for instance, resulting from more rapid fertility decline in big cities), to an extent that more than offsets high net migration into cities. These hypotheses warrant investigation to reveal the demographic and economic underpinnings and policy instruments in rural areas that affect the pace of city growth.

\section{SOURCES OF NATIONAL URBAN GROWTH SINCE 1980}

In addition to examining sources of city population growth since the 1970 s, causes of national urban population growth since 1980 also merit investigation, with reference to predictions of national-level urban growth made around 1980. Kelley and Williamson (1984a and 1984b) examined whether the rate of urban growth in developing countries during 1973-79 would have differed in the absence of the major increase in oil prices and related economic conditions that prevailed in those years. Their analysis was exceptional in considering economywide influences on urban growth in an "open" setting, in which migration between rural and urban areas is affected by exogenous forces that confront an entire country. The study found that the average annual urban growth rate of a "representative" developing country (4.65 percent) would have been much highermore closely approximating the rate during 1960-73-if urban-based manufacturing had not declined relative to rural-based agriculture in terms of trade and productivity. ${ }^{14}$ In contrast, the slow growth of agricultural land stock and high growth of the population of labor force age-factors that presumably "push" surplus rural population toward urban areas-as well as foreign capital inflow and the higher price of fuels and raw materials did not affect the pace of urban growth. Kelley and Williamson concluded that imbalance between manufacturing and agriculture matters most to urban growth, in part by instigating (or inhibiting) migration to urban centers of employment and economic advantage. Continuation of unfavorable trends in manufacturing relative to agriculture therefore would indicate slower rates of urban growth in the 1980s and 1990s than would be expected otherwise.

Table 5 presents the key findings of Kelley and Williamson and comparable results from an analysis of data from 95 developing countries representing the period 
Table 5 Effects of economywide variables on the national urban growth rate (UGR) in LDCs, 1973-79 and 1980-96

\begin{tabular}{|c|c|c|c|c|c|c|c|}
\hline \multirow[b]{3}{*}{ Variable } & \multicolumn{3}{|c|}{ Kelley and Williamson, 1973-79 } & \multicolumn{4}{|c|}{ Observed, 1980-96 } \\
\hline & \multirow[b]{2}{*}{ Assumption } & \multirow[b]{2}{*}{ Counterfactual } & \multirow{2}{*}{$\begin{array}{l}\text { UGR from } \\
\text { counterfactual }\end{array}$} & \multicolumn{3}{|c|}{ Median annual UGR for countries } & \multirow{2}{*}{$\begin{array}{l}\text { Effect of variable on } \\
\text { average annual UGR }\end{array}$} \\
\hline & & & & Mean & $>$ Mean & $\leq$ Mean & \\
\hline \multicolumn{8}{|l|}{$\begin{array}{l}\text { Unbalanced factor productivity } \\
\text { (agriculture growth / } \\
\text { manufacturing growth), }\end{array}$} \\
\hline$\%$ per annum & 0.8 & 0.5 & 5.86 & 0.89 & 3.65 & 4.83 & $-0.296 *$ \\
\hline $\begin{array}{l}\text { Relative price of manufactures, } \\
\% \text { growth per annum }\end{array}$ & -1.6 & 0 & 6.49 & -0.97 & 5.30 & 2.89 & $-0.735^{*}$ \\
\hline $\begin{array}{l}\text { Foreign capital inflow } \\
\text { per annum, as \% of GDP }\end{array}$ & 3.0 & 0 & 4.67 & 1.26 & 4.11 & 4.01 & 0.137 \\
\hline $\begin{array}{l}\text { Agricultural land stock, } \\
\% \text { growth per annum }\end{array}$ & 0.5 & 1.0 & 4.61 & 0.83 & 4.02 & 4.13 & 0.083 \\
\hline $\begin{array}{l}\text { Labor force, \% growth per } \\
\text { annum }\end{array}$ & 2.68 & 2.54 & 4.60 & 2.50 & 4.46 & 3.92 & 0.261 \\
\hline $\begin{array}{l}\text { Percent of population } \\
\text { aged } 65 \text { or older in } 1980\end{array}$ & - & - & - & 4.20 & 3.24 & 4.83 & $-0.279 *$ \\
\hline $\begin{array}{l}\text { Proportion of population } \\
\text { aged } 65 \text { or older, \% growth } \\
\text { per annum }\end{array}$ & - & - & - & 0.74 & 3.31 & 4.85 & $-0.412^{*}$ \\
\hline $\begin{array}{l}\text { Policy in } 1980 \text { to curb urban } \\
\text { growth }(1=y e s, 0=\text { no) }\end{array}$ & - & - & - & 0.40 & Yes: 3.53 & No: 4.88 & $-0.713^{*}$ \\
\hline $\begin{array}{l}\text { Size of country (sq. miles, } \\
\text { in thousands) }\end{array}$ & - & - & - & 226,411 & 4.01 & 4.13 & $\begin{array}{l}-0.002 \\
\text { Constant }=1.292\end{array}$ \\
\hline$N=(40)$ & (Actual a & vg. UGR = 4.65) & & (Actual & g. $U G R=4$ & 05) & $\begin{array}{l}\mathrm{R}^{2}=.577 \\
\mathrm{~N}=(95)\end{array}$ \\
\hline
\end{tabular}


1980-96. Variables examined for recent years are those identified as potent causes of urban growth during 1973-79 (and, implicitly, before and after those years) as well as factors deemed insignificant at that time but nonetheless apposite to consideration of the influence of population pressures on urban growth since 1980. The importance of four nationwide factors that could have reduced urban growth in part by depressing migration from the countryside is also examined: (1) the percentage of population aged 65 or older in 1980; (2) the growth rate of the proportion of the population age 65 or older during 1980-96; (3) a policy in 1980 to alter the spatial distribution of population-as defined by the simultaneous existence of a negative perception by government of the population distribution, intention to decelerate or reverse migration flows, and intention to modify the rural/urban configuration of settlements (United Nations 1981); and (4) country size in terms of area, which when large might indicate a greater distance between rural and urban places. An alternative to counterfactuals - values that Kelley and Williamson derived from historical data and expert opinion and that presumably approximate conditions prior to the rise of oil prices-is used to determine the impact of national trends and conditions on urban growth. Additionally, analysis of data for 1980 96 shows the mean values of variables among these 95 countries as recorded by the United Nations and the World Bank, presents the median annual urban growth rates for countries that experienced values above and below the means, and estimates the linear effects of variables on the urban growth rate. ${ }^{15}$

A substantial technological slowdown has occurred in the developing world since 1980 (encompassing the so-called lost decade of the 1980s), and the price "squeeze" on the agricultural sector has been reduced. These trends are reflected by the much higher productivity increase in rural agriculture as compared to urban manufacturing (at 0.89 percent per annum, even exceeding OPEC-period levels) and by the price decline of manufactures relative to agricultural goods (at -0.97 percent per annum). Countries that experienced lower than average relative growth in manufacturing had a median annual urban growth rate of 3.65-or 0.4 percentage points lower than all countries on average, and about 1.2 percentage points lower than countries with comparatively strong manufacturing growth. Among countries where the price of manufactures fell by more than 0.97 percent yearly as compared to agricultural prices, the median annual urban growth rate was 2.89 - or 1.2 percentage points lower than the aggregate average and just over 
half the rate of countries where price trends have been more favorable to manufactures. The effect of these sector productivity trends during 1980-96, quite disadvantageous to manufacturing, was to reduce the average annual urban growth rate by 0.3 percentage points. Likewise, declining relative prices for manufactures reduced the rate by 0.74 percentage points. In sum, results indicate that, as in the 1970s, the sluggish performance of manufacturing (as compared to agriculture) remains largely responsible for the observed slower pace of urban growth in developing countries, and may have decelerated urban growth from what otherwise would have been higher rates in the 1980s and 1990s by curbing net rural-to-urban migration.

Sustained periods of reduced international capital inflows experienced by many countries since the 1980s might be expected to have dampened urban growth—given that most capital inflows (hence income-earning opportunities) typically come to cities-but strong evidence remains that, for LDCs on the whole, the level of foreign capital inflow over time has had no significant effect on the pace of urban growth. Likewise, agricultural land expansion and the rate of growth of the population of labor force age (the main contributor to urban fertility and net rural-to-urban migration) have had negligible effects on urban growth. In all, despite the use of more-limited data for a much earlier period, Kelley and Williamson were remarkably on target in identifying those overarching forces that do, and do not, determine rates of urban growth in developing countries.

Of the additional variables considered here, size of country turns out to be unimportant, but population aging appears to be crucial. Aging populations would logically be associated with slower national population growth, but their relationship to the pace of urban growth is undocumented. Many developing countries, notably in Latin America and the Caribbean, had high proportions of elderly persons among their populations in 1980 or earlier (US Bureau of the Census 1992: Table 5). Those countries with percentages of persons aged 65 or older exceeding 4.2 experienced urban growth rates 0.8 percentage points lower than average. Moreover, a yearly increase of one percent in the proportion of population aged 65 or older (for instance, from 5 percent to 5.05 percent) - a value slightly higher than the 0.74 percent mean increase per annum observed in our sample-reduces the urban growth rate by 0.41 percentage points (for instance from 4.05 percent to 3.64 percent). The difference in median urban annual growth rates 
between countries that experienced higher and lower rates of growth in their proportion of elderly persons than the mean exceeds 1.5 percentage points ( 3.31 percent as compared to 4.85 percent per annum).

High levels and rapidly growing proportions of elderly persons could reduce urban growth through several mechanisms. These include, most directly, lower and declining urban fertility and decreased propensity among the aging rural population to resettle in urban areas (if rural-to-urban migration is prompted mainly by job, school, or marriage prospects). On the other hand, the concentration and growth of the elderly population in developing countries may be largely an urban phenomenon-given that curative health care services are overwhelmingly based in cities in many countries, while higher fertility persists in the countryside. Unfortunately, no comprehensive data on the age structures of urban and rural populations exist to examine these arguments. Without engaging in undue speculation, suffice it to say that the more-rapid growth expected in the future of the proportion of population aged 65 or older in developing countries-at 2.1 percent per annum between 2000 and 2025 , to represent over 8 percent of the total population by the end of the period (according to the UN medium-variant projections) implies a potentially strong dampening effect on rates of urban growth. Whether changing age structures reduce urban growth purely through urban fertility decline or are associated with it through other linkages is a question for future research.

Spatial aspects of population policy appear more significant to curbing urban growth than is conventionally assumed on the basis of the failed "migration policies" of many governments in the 1960s and 1970s (Simmons 1981). Measures implemented to modify the distribution of population, including migration policies, substantially reduced the average annual rate of urban growth in LDCs during 1980-96, by about 0.7 percentage points, and likely would have had a greater dampening impact on urbanization in the developing world if applied in more countries. Admittedly, the policy indicators are crude, as they reflect governments' perceptions of the comparative desirability of alternative spatial patterns, not their actual interventions, and they are reported to the United Nations by potentially biased or not well-informed offices of government. Nonetheless, many countries that viewed their population distributions as unacceptable and acted to change them - for instance, Mexico, Egypt, and India- experienced lower urban growth rates during 1980-96 than did their global subregions, and much lower growth 
than neighboring countries-Guatemala, Sudan, Bangladesh-that had less negative stances on urban growth. This result points to a need to identify which migration-related policies most influence urban growth-for instance, rural development schemes versus the imposition of eligibility requirements for movement from the countryside. In the absence of such research, and given the strong effect of migration policy on urban growth independent of economic and demographic conditions, one cannot dismiss spatial distribution policies as uniformly ineffective instruments to manage the urban transition.

\section{CONCLUSION}

While short-range population projections sometimes prove imprecise, the large downward revision of the projected size of the urban population of most developing countries in the year 2000 — based on a considerable amount of accumulated evidencesuggests that a slowdown of urban growth has occurred since the 1970s. A much-modified picture of the "urban population explosion" in recent years reflects the effects of relatively weak expansion of urban industries and price shifts unfavorable to manufactured goods, population aging, policies to alter migration and spatial distribution patterns in some countries, and no doubt other forces not examined in this analysis. National population growth rates that produce less than commensurate city growth rates, net of other factors, suggest that reduced net rural-to-urban migration has been a principal demographic component of slower-than-expected urban growth. However, the continued absence of timely, adequate data on rural-to-urban migration in most developing countries, as well as on natural increase in urban and rural areas separately, precludes attribution of the slowdown of urban growth in most countries to any single demographic process (or to statistical changes due to such causes as redrawing of city boundaries or reclassification of urban places). Further clarification of the demographic underpinnings of urban growth—rather than of its underlying economic and social causes examined here-awaits analysis of data from the 2000-round censuses.

It remains to be seen whether economic downturns and other recent trends have just temporarily slowed the process of the urban population transition in the developing world-as implied by current projections that anticipate rapid urban growth and very

large population increments in cities in the next few decades-or whether conditions of the 1980s and 1990s have a more lasting effect on the future growth and size of the 
urban population. Comparison of the biennial urban estimates and projections issued by the United Nations with earlier data, as done here with reference to the 1996 revision, on a routine basis would shed light on this issue provided that the UN methodology is not altered in future estimates and projections.

The discrepancy between early and the most recent urban population projections is no doubt attributable, in part, to the continued inadequacy of the underlying data on which these projections are based; urban population statistics should be interpreted with caution. As illustrated above, however, the increased availability of basic population, economic, and geographic data for most developing countries in the last 20 years now enables detailed analysis of the causes of urban growth. With few exceptions (for instance, Becker, Hamer, and Morrison 1994; McGee and Robinson 1995), this topic has been neglected for some time, despite its obvious demographic significance. This article has revisited notable examples of research on sources of urban and city growth in the 1960s and 1970s and has derived results that inform our understanding of the causes of growth since that time (either through confirmation or refutation of earlier findings). An apparent priority for future research is to determine whether policy interventions of governments can hasten the pace of urban growth, if more rapid growth is deemed desirable on economic or other grounds. Alternatively, research might determine whether the pace of urban growth in developing countries can be controlled by governments if, for instance, doing so is suggested by global economic conditions or by demographic conditions identified in this study. Fortunately, sufficient data are becoming available in some countries to address these and other questions pertinent to the growth of cities and urban populations.

\section{Notes}

1 Mexico City's population increased from 5.4 million in 1960 to 13 million in 1980 (Garza 1999: 153). By simply extrapolating this rate of growth, the UN projected a population size of 31.3 million by the year 2000 .

2 The method for projecting city size, however, has been changed (see United Nations 1998: 33-36). National urban and rural projections made in 1980 and 1996 may both be flawed as a result of the UN's methodology. Much potential inaccu- 
racy may be associated with the central measure used in calculations, a single urban-rural growth differential derived from 228 countries in both developing and developed regions and applied hypothetically to each individual country (including those 22 countries with no definition of an urban area, and 8 countries where all population officially resides in areas designated as urban or rural). For urban population projections of individual countries, the use of data from other countries inevitably introduces potential error (even if the hypothetical differential, properly weighted, applies to countries at any level of urbanization). At national and higher levels of population aggregation, the UN's urban projections may also prove inaccurate if any of numerous assumptions are violated: for instance, if the urban-rural growth differential assumes a negative value, as it has in Oceania since the late 1970s; if the exclusion of countries with small populations from the procedure produces a less, not more, valid hypothetical differential; if the linear incremental weights applied to the differential over successive five-year intervals are inappropriate; and so forth. However, since the method has remained constant between 1980 and 1996, all discrepancy in projections between the two dates that results from the method would originate from changes in the country-level data that enter into the procedure (including their source, amount, timeliness, and validity in measuring demographic events).

3 Almost no developing country changed its official definition of urban between 1980 and 1996. The few countries that did change their definition-for instance, Afghanistan, Benin, and Iran-did so in a manner that did not change the locales classified as urban. The UN urban projection method allows for the graduation of rural areas to urban areas (and vice versa) based on population size criteria, and therefore does not invalidate the trends shown in Table 1.

4 The extent to which over-projection of the urban population in 1980 is attributable to over-projection of the total population varies by region. For instance, the projected urban population of Africa in 2000 has been revised downward by about 36 million since 1980, whereas the projected total population of Africa in 2000 has been revised upward by about 6 million. In this case, none of the downward revision of the projected urban population can be attributed to slower total popu- 
lation growth in Africa than was expected in 1980. In contrast, the projected urban population of Latin America and the Caribbean has been revised downward by about 79 million, while the projected total population of the region has been revised downward by 105 million. Therefore, in Latin America and the Caribbean one could attribute all of the over-projection of the urban (and rural) population to slower-than-expected growth of the total population. The point to emphasize is that errors in projecting urban populations are affected by errors in projecting total populations.

As recently as 1988, for instance, the UN's medium variant projection of the total fertility rate (TFR) in less developed regions in 1990-95 was 3.69 (United Nations 1989). The UN now estimates that the TFR during this period was 3.27 (United Nations 1999). Admittedly, the current estimate includes some relatively low-fertility developing countries that were formerly part of the Soviet Union whereas the earlier projection did not, but these countries in sum account for a very small proportion of the developing world's population. Countries with populations of less than 2 million in 1995 are not examined, because small absolute changes in their projected urban population sizes may have resulted in such large percentage changes that comparison with larger countries is misleading.

7 Faster-than-expected urbanization and urban growth in Nigeria since 1980 are especially intriguing insofar as the structural adjustment policies imposed in that country by international financial institutions in the 1980s (though not strictly adhered to by the governments) would be expected to have reduced migration to cities and perhaps to have lowered urban fertility (Olu Abiodun 1997). A plausible explanation for the revision of the size of Nigeria's (and Lagos's) urban population is that estimates and projections have been based on poor-quality census data, particularly preceding the 1991 census.

8 In the 1980s, China established hundreds of new cities and thousands of new towns with extraordinarily large land areas. This reclassification of rural places 
as urban greatly magnified the size of China's urban population (for instance, it raised the proportion classified as urban from 21 percent in 1982 to 57 percent in 1990). To correct for this change in definition, the State Statistical Bureau created a second, more realistic definition of urban applied to the 1990 census, which defines the urban population as including urbanized residents of neighborhood committees.

9 Mohan (1996) speculates from 1991 census data that would-be migrants to cities were discouraged from moving by the lack of jobs and a worsening quality of urban life in the 1980s.

10 These represent all cities in developing regions with a population of at least 750,000 in 1995 (United Nations 1998) whose projected populations to 2000 can be traced to those included in United Nations (1980).

11 For China, data are taken from the 1982 and 1990 national population censuses.

12 In this case, counter-urbanization would be defined as the movement of people away from cities, regardless of city size criteria, toward smaller areas, including suburbs or peri-urban areas not officially recognized as part of the city proper. Descriptive accounts of this process in the 1980s for large as well as small cities are given by Gilbert (1996) and UNCHS (1996). History suggests that in regions where urbanization levels are relatively low, such as South Asia and sub-Saharan Africa, counter-urbanization would be fleeting; it may reflect the more adverse impact on cities than on other areas of economic downturns in the 1970s-1990s.

13 Detailed explanations of recent city growth patterns in China and India, respectively, are found in Scharping (1997) and Mohan (1996).

14 Data for a representative developing country were based on unweighted averages of 40 countries. These developing countries included only "price-takers" in international trade-therefore excluding net oil-exporting countries of OPECand countries with favorable economic situations between 1960 and 1973. The present analysis of 95 developing countries during 1980-96 includes any of these 
formerly omitted states for which suitable and complete data are available, since the capacity of these countries in dictating global fuel prices has greatly diminished since 1980, and because economic forces unfavorable to rapid urban growth prevailed in most developing countries in the 1980s and early 1990s (with the exception of some Asian countries that experienced rapid economic growth during that period).

The characterization of manufacturing as "urban" and agriculture as "rural" is somewhat inaccurate, especially in countries where "mega-urbanization" or metropolitan sprawl has dispersed industries to adjacent rural areas (McGee and Robinson 1995), or where export-oriented manufacturing has been established in rural hinterlands (for instance, in "New Economic Zones" of countries in Southeast Asia and the Caribbean). Even in this minority of developing countries, however, the manufacturing and agricultural sectors are overwhelmingly concentrated in urban and rural areas, respectively.

15 For some small countries, data taken from the World Bank World Development Indicators 1998 are available only in CD-ROM format, not in publication.

\section{References}

Badshah, Akhtar A. 1996. Our Urban Future: New Paradigms for Equity and Sustainability. London and New Jersey: Zed Books.

Banister, Judith. 1997. "China: Internal and regional migration trends," in Scharping 1997: 72-97.

Bairoch, Paul (translated by Christopher Braider). 1988. Cities and Economic Development: From the Dawn of History to the Present. Chicago: University of Chicago Press.

Becker, Charles M., Andrew M. Hamer, and Andrew R. Morrison. 1994. Beyond Urban Bias in Africa: Urbanization in an Era of Structural Adjustment. Portsmouth, NH: Heinemann.

Becker, Charles M. and Andrew R. Morrison. 1999. "Urbanization in transforming econo- 
mies," in Paul Cheshire and Edwin S. Mills (eds.), Handbook on Applied Urban Economics. New York: Oxford University Press, pp. 1673-1790.

Bocquier, Philippe and Sadio Traoré. 1998. "Migration and urbanization in West Africa: Methodological issues in data collection and inference," in Richard E. Bilsborrow (ed.), Migration, Urbanization, and Development: New Directions and Issues. New York: United Nations Population Fund and Kluwer Academic Publishers, pp. 249-273.

Boserup, Ester. 1965. The Conditions of Agricultural Growth: The Economics of Agrarian Change under Population Pressure. Chicago: Aldine.

Brockerhoff, Martin and Ellen Brennan. 1998. "The poverty of cities in developing regions," Population and Development Review 24(1): 75-114.

Davis, Kingsley. 1963. "The theory of change and response in modern demographic history," Population Index 29(4): 345-366.

Garza, Gustavo. 1999. "Global economy, metropolitan dynamics and urban policies in Mexico," Cities 16(3): 149-170.

Gilbert, Alan (ed.). 1996. The Mega-City in Latin America. Tokyo: United Nations University Press.

Kelley, Allen C. and Jeffrey G. Williamson. 1984a. "Population growth, industrial revolutions, and the urban transition," Population and Development Review 10(3): 419-441.

_. 1984b. What Drives Third World City Growth? A Dynamic General Equilibrium Approach. Princeton: Princeton University Press.

Lipton, Michael. 1976. Why Poor People Stay Poor: Urban Bias in World Development. Cambridge, MA: Harvard University Press.

McGee, T. G. and Ira M. Robinson. 1995. The Mega-Urban Regions of Southeast Asia. Vancouver: University of British Columbia Press.

Mohan, Rakesh. 1996. "Urbanization in India: Patterns and emerging policy issues," in Josef Gugler (ed.), The Urban Transformation of the Developing World. Oxford: Oxford University Press, pp. 93-131. 
Olu Abiodun, Josephine. 1997. "The challenges of growth and development in metropolitan Lagos," in Carole Rakodi (ed.), The Urban Challenge in Africa: Growth and Management of Its Large Cities. Tokyo: United Nations University Press, pp. 192-222.

Preston, Samuel H. 1979. "Urban growth in developing countries: A demographic reappraisal," Population and Development Review 5(2): 195-215.

Satterthwaite, David. 1996. The Scale and Nature of Urban Change in the South. London: International Institute for Environment and Development, Human Settlements Programme.

Scharping, Thomas (ed.). 1997. Floating Population and Migration in China: The Impact of Economic Reforms. Hamburg: Institut für Asienkunde.

Schiffer, Robert L. 1989. The Exploding City: An Unforgettable Journey Through Nine Great Cities. New York: St. Martin's Press.

Simmons, Alan B. 1981. "A review and evaluation of attempts to constrain migration to selected urban centres and regions," papers of the United Nations/UNFPA Workshop on Population Distribution Policies in Development Planning, Bangkok, 4 13 September 1979, Population Distribution Policies in Development Planning. New York: United Nations.

United Nations. 1980. Patterns of Urban and Rural Population Growth. New York.

- 1981. World Population Trends and Policies: 1981 Monitoring Report, Volume I, Population Trends. New York: United Nations, Department of International Economic and Social Affairs.

- 1989. World Population Prospects 1988. New York: United Nations, Department of International Economic and Social Affairs.

1998. World Urbanization Prospects: The 1996 Revision. New York: United Nations, Department of Economic and Social Affairs, Population Division. 1999. World Population Prospects: The 1998 Revision. New York: United Nations Secretariat, Department of Economic and Social Affairs, Population Division. 
. 1971-1997. (Selected volumes). Demographic Yearbook. New York: United Nations Secretariat, Department of Economic and Social Affairs, Population Division.

United Nations Center for Human Settlements (UNCHS). 1996. An Urbanizing World: Global Report on Human Settlements, 1996. Oxford: Oxford University Press for HABITAT.

US Bureau of the Census. 1991. World Population Profile: 1991 (Report WP/91). Washington, DC: US Government Printing Office.

—_ 1992. An Aging World II (International Population Reports, P25, 92-3). Washington, DC: US Government Printing Office.

World Bank. 1977-1997 (Selected volumes). World Development Report. New York: Oxford University Press.

- 1985, 1995. World Tables. Baltimore and London: Johns Hopkins University Press.

. 1998. World Development Indicators. Washington, DC: The World Bank. 


\title{
POLICY RESEARCH DIVISION WORKING PAPERS
}

\author{
Recent Back Issues
}

93 James F. Phillips, Fred N. Binka, Martin Adjuik, Alex Nazzar, and Kubaze Frank Adazu, "The determinants of contraceptive innovation: A case-control study of family planning acceptance in a traditional African society."

*94 John Bongaarts and Sajeda Amin, "Prospects for fertility decline and implications for population growth in South Asia."

95 Barbara S. Mensch and Cynthia B. Lloyd, "Gender differences in the schooling experiences of adolescents in low-income countries: The case of Kenya."

96 Martin Brockerhoff and Ellen Brennan, "The poverty of cities in the developing world."

*97 Carol E. Kaufman, "Reproductive control in South Africa."

*98 John Bongaarts, "Trends in unwanted childbearing in the developing world."

99 Mary Arends-Kuenning, "How do family planning workers' visits affect women's contraceptive behavior in Bangladesh?"

* No longer available
100 Mark R. Montgomery and Cynthia B. Lloyd, "Excess fertility, unintended births, and children's schooling."

101 Mary Arends-Kuenning, "The equity and efficiency of doorstep delivery of contraceptives in Bangladesh."

*102 Sajeda Amin, Ian Diamond, Ruchira T. Naved, and Margaret Newby, "Transition to adulthood of female factory workers: Some evidence from Bangladesh."

*103 Margaret E. Greene and Ann E. Biddlecom, "Absent and problematic men: Demographic accounts of male reproductive roles."

104 Michael P. Todaro, "Urbanization, unemployment, and migration in Africa: Theory and policy."

105 Geoffrey McNicoll, "Population and poverty: A review and restatement." 
106 Sajeda Amin and Gilda Sedgh, "Incentive schemes for school attendance in rural Bangladesh."

107 Martin Brockerhoff and Paul Hewett, "Ethnicity and child mortality in subSaharan Africa."

108 Ann E. Biddlecom and Bolaji M. Fapohunda, "Covert contraceptive use: Prevalence, motivations, and consequences."

109 John Bongaarts and Griffith Feeney, "On the quantum and tempo of fertility."

110 Barbara S. Mensch, Daniel Bagah, Wesley H. Clark, and Fred Binka, "The changing social environment for adolescents in the Kassena-Nankana District of northern Ghana: Implications for reproductive behavior."

111 Martin Brockerhoff and Ann Biddlecom, "Migration, sexual behavior, and HIV diffusion in Kenya."

112 Zeba A. Sathar and John B. Casterline, "The onset of fertility transition in Pakistan."

113 Geoffrey McNicoll, "Government and fertility in transitional and posttransitional societies."
114 John Bongaarts, "Fertility and reproductive preferences in post-transitional societies."

115 Fiona Steele, Sajeda Amin, and Ruchira T. Naved, "The impact of an integrated micro-credit program on women's empowerment and fertility behavior in rural Bangladesh."

*116 Cynthia B. Lloyd, Barbara S. Mensch, and Wesley H. Clark, "The effects of primary school quality on the educational participation and attainment of Kenyan girls and boys."

117 Sajeda Amin and Cynthia B. Lloyd, "Women's lives and rapid fertility decline: Some lessons from Bangladesh and Egypt."

118 James F. Phillips and Mian Bazle Hossain, "The impact of family planning household service delivery on women's status in Bangladesh."

119 Mark R. Montgomery and John B. Casterline, "Social networks and the diffusion of fertility control."

\footnotetext{
* No longer available
} 
120 John Bongaarts, "The fertility impact of changes in the timing of childbearing in the developing world."

121 James F. Phillips, Wendy L. Greene, and Elizabeth F. Jackson, "Lessons from community-based distribution of family planning in Africa."

122 Mark R. Montgomery, "Mortality decline and the demographic response: Toward a new agenda."

123 Mark R. Montgomery, Mary ArendsKuenning, and Cem Mete, "The quantity-quality transition in Asia."

124 Barbara S. Mensch, Wesley H. Clark, Cynthia B. Lloyd, and Annabel S. Erulkar, "Premarital sex and school dropout in Kenya: Can schools make a difference?"

125 John Bongaarts and Rodolfo A. Bulatao, "Completing the demographic transition."

126 Geoffrey McNicoll, "Population weights in the international order."
127 Cynthia B. Lloyd, Carol E. Kaufman, and Paul Hewett, "The spread of primary schooling in sub-Saharan Africa: Implications for fertility change."

128 John B. Casterline, "The onset and pace of fertility transition: National patterns in the second half of the twentieth century."

129 Mark R. Montgomery, Michele Gragnolati, Kathleen Burke, and Edmundo Paredes, "Measuring living standards with proxy variables."

130 Bamikale Feyisetan and John B. Casterline, "Fertility preferences and contraceptive change in developing countries."

131 Martin Brockerhoff, "Urban growth in developing countries: A review of projections and predictions." 